\title{
Long-Term Passive Integrated Transponders (PIT) Tag Retention in Juvenile Rainbow Trout and Brown Trout
}

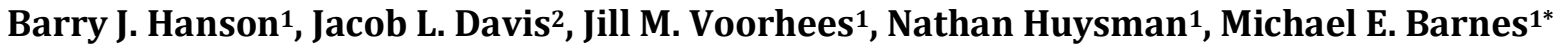 \\ ${ }^{1}$ Department Game, Fish and Parks, McNenny State Fish Hatchery, Spearfish, SD, USA \\ ${ }^{2}$ Department Game, Fish and Parks, Outdoor Campus West, Rapid City, SD, USA \\ Email: *mike.barnes@state.sd.us
}

How to cite this paper: Hanson, B.J., Davis, J.L., Voorhees, J.M., Huysman, N. and Barnes, M.E. (2020) Long-Term Passive Integrated Transponders (PIT) Tag Retention in Juvenile Rainbow Trout and Brown Trout. Open Journal of Marine Science, 10, 110-115.

https://doi.org/10.4236/ojms.2020.103008

Received: April 28, 2020

Accepted: May 22, 2020

Published: May 25, 2020

Copyright $\odot 2020$ by author(s) and Scientific Research Publishing Inc. This work is licensed under the Creative Commons Attribution International License (CC BY 4.0).

http://creativecommons.org/licenses/by/4.0/

\begin{abstract}
Two hundred and forty-three juvenile rainbow trout Oncorhynchus mykiss ranging from 73 to $119 \mathrm{~mm}$ were implanted with 8, 9, or $10 \mathrm{~mm}$ Passive Integrated Transponder (PIT) tags, with tag retention and fish survival observed for 343 days. Similarly, 173 brown trout Salmo trutta ranging from 71 to 86 $\mathrm{mm}$ were implanted with 8 or $10 \mathrm{~mm}$ PIT tags and observed for 293 days. Over the entire duration of the study, rainbow trout ejected only six tags, while no tags were ejected from the brown trout. All of the rainbow trout tag ejections occurred before 50 days post-tagging. There was no significant difference in the length or weight of fish that ejected tags compared to those that retained tags. No fish died during the trials. These results indicate that rainbow trout and brown trout at the sizes used in this study can be safely implanted with, and subsequently retain, up to $10 \mathrm{~mm}$ PIT tags for durations of nearly one year.
\end{abstract}

\section{Keywords}

Tagging, Salmonids, Passive Integrated Transponders, PIT Tag, Fingerling

\section{Introduction}

Passive Integrated Transponders (PIT) are relatively small, injectable, long-lasting tags emitting unique alphanumeric codes [1] [2]. The codes can be read remotely without having to look at the tag, thereby allowing the tag data to be obtained without having to physically handle the tagged fish [3] [4]. PIT tags are routinely used in fisheries management, particularly when assessing individual fish behavior, growth, and mortality [5] [6] [7] [8] [9]. 
The relationship between fish size and tag size has a direct effect on the survival of the tagged fish and retention of the tag [3] [10] [11]. This relationship is based almost exclusively on studies evaluating larger fish tagged with larger PIT tags; only Borchert et al. [12] examined the use of small pit tags in smaller, juvenile salmonids. However, Borchert et al. [12] only examined tag loss and fish survival for approximately five months after tagging.

Juvenile fish survival and growth is of interest to fisheries managers but is frequently lacking [13] [14]. Thus, additional information on long-term PIT tag retention and the survival of juvenile PIT tagged fish is needed. The objective of this study was to evaluate the implantation of small PIT tags in two species of juvenile salmonids for a very extended time frame.

\section{Methods}

This study was a continuation of the Borchert et al. [12] trial but extended the data collection period to 343 days for juvenile rainbow trout Oncorhynchus mykiss and 293 days for brown trout Salmo trutta.

Trout were anesthetized to stage 4 anesthesia [15] with tricaine methanosulfate (MS-222; Syndel, Ferndale, Washington, USA). A PIT tag (MiniHPT8, HPT9, or MiniHPT10; Biomark, Boise, Idaho, USA) was then implanted using a handheld injector into the peritoneal cavity. Each fish was then measured to the nearest $\mathrm{mm}$ and weighed to the nearest $0.1 \mathrm{~g}$. The unique 12-digit alphanumeric identification number was then obtained using a HPR Lite reader (Biomark, Boise, Idaho, USA). All of the tagged fish were placed into one, $1.8-\mathrm{m}$ diameter circular tank receiving well water $\left(11^{\circ} \mathrm{C}\right.$; total hardness as $\mathrm{CaCO}_{3}, 360 \mathrm{mg} / \mathrm{L}$ : alkalinity as $\mathrm{CaCO}_{3}, 210 \mathrm{mg} / \mathrm{L} ; \mathrm{pH}, 7.6$; total dissolved solids, $390 \mathrm{mg} / \mathrm{L}$ ). They were fed to satiation or slightly above satiation once daily $(1.5 \mathrm{~mm}$ floating PROTEC FW, Skretting North America, Tooele, Utah, USA). Tagging, rearing, and data collection occurred at McNenny State Fish Hatchery, Spearfish, South Dakota, USA. Tag retention was checked weekly for the first three weeks after tagging and monthly there-after. Total lengths and weights were recorded from any fish that ejected tags.

Rainbow trout were tagged on February 11, 2019 with either 8, 9, or $10 \mathrm{~mm}$ PIT tags. Brown trout were tagged on April 1, 2019 with either 8 or $10 \mathrm{~mm}$ tags. Final tag checks occurred on January 20, 2020. Initial fish lengths, weights, and the PIT tag sizes used are listed in Table 1.

Data were analyzed using the SPSS (24.0) statistical analysis program (IBM, Armonk, New York, USA). Percentage data were log transformed prior to analysis of variance to stabilize the variances [16]. Retention data was analyzed using Pearson's chi-square tests. Length and weight comparisons between trout that either lost or retained tags were conducted using two-sample t-tests. To evaluate differences in final total length and weight among the tag sizes, Kruskal-Wallis One Way Analysis of Variance on Ranks was used. Significance for all tests was predetermined at $\mathrm{P}<0.05$. 


\section{Results}

All of the juvenile brown trout retained their PIT tags, compared to $97.5 \%$ of the juvenile rainbow trout (Table 2). Tag size-specific retention rates in the rainbow trout were as follows: $8 \mathrm{~mm}$-95.9\%; $9 \mathrm{~mm}-98.8 \%$; $10 \mathrm{~mm}-98.4 \%$. Only rainbow trout lost tags over the course of the 343-day trial, and all tag ejections occurred before 50 days post-tagging. Three tags were lost within the first eight days, one tag was lost after day nine and before day 15, and two tags were lost between days 22 and 50. There was no significant difference in length or weight in the rainbow trout that either retained or ejected their tags, nor was there any significant difference in retention rates among the three sizes of tags. There were no significant differences in either rainbow trout or brown trout final lengths or weights among the different tag groups. The final tank rearing density was 56.8 $\mathrm{kg} / \mathrm{m}^{3}$. No mortalities were observed during the study period.

\section{Discussion}

This study extended the positive results of tag retention and tagged fish survival

Table 1. Initial minimum, maximum, and mean (SD) total lengths and weights of rainbow trout and brown trout implanted with different size passive integrated transponders.

\begin{tabular}{ccccccccc}
\hline \multirow{2}{*}{ Species } & \multirow{2}{*}{ Tag size } & \multicolumn{3}{c}{ Length (mm) } & \multicolumn{3}{c}{ Weight (g) } & \multirow{2}{*}{ N } \\
\cline { 3 - 7 } & & Min & Max & Mean (SD) & Min & Max & Mean (SD) & \\
\hline Rainbow trout & 8 & 80 & 119 & $100(8)$ & 5 & 20 & $12(3)$ & 98 \\
& 9 & 73 & 117 & $100(9)$ & 4 & 19 & $12(3)$ & 82 \\
& 10 & 78 & 118 & $99(8)$ & 6 & 21 & $12(3)$ & 63 \\
Brown trout & Overall & 73 & 119 & $100(8)$ & 6 & 21 & $12(3)$ & 243 \\
& 10 & 71 & 83 & $76(3)$ & 4 & 7 & $5(1)$ & 88 \\
& 10 & 71 & 86 & $76(3)$ & 4 & 8 & $5(1)$ & 89 \\
& Overall & 71 & 86 & $76(3)$ & 4 & 8 & $5(1)$ & 177 \\
\hline
\end{tabular}

Table 2. Final minimum, maximum, and mean (SD) total lengths, weights, and tag retention of rainbow trout and brown trout implanted with different size passive integrated transponders.

\begin{tabular}{|c|c|c|c|c|c|c|c|c|c|}
\hline \multirow[t]{2}{*}{ Species } & \multirow[t]{2}{*}{ Tag size } & \multicolumn{3}{|c|}{ Length (mm) } & \multicolumn{3}{|c|}{ Weight (g) } & \multirow[t]{2}{*}{ Ret. (\%) } & \multirow[t]{2}{*}{$\mathbf{N}$} \\
\hline & & Min & $\operatorname{Max}$ & Mean (SD) & Min & $\operatorname{Max}$ & Mean (SD) & & \\
\hline \multirow{4}{*}{$\begin{array}{c}\text { Rainbow } \\
\text { trout }\end{array}$} & 8 & 193 & 339 & $281(23)$ & 93 & 480 & $300(71)$ & 95.9 & 94 \\
\hline & 9 & 178 & 339 & $278(29)$ & 77 & 534 & $292(85)$ & 98.8 & 81 \\
\hline & 10 & 209 & 343 & $283(24)$ & 156 & 529 & $310(80)$ & 98.4 & 62 \\
\hline & Overall & 178 & 343 & $280(26)$ & 77 & 534 & $300(79)$ & 97.5 & 237 \\
\hline \multirow{3}{*}{$\begin{array}{c}\text { Brown } \\
\text { trout }\end{array}$} & 8 & 161 & 289 & $192(18)$ & 57 & 351 & $99(35)$ & 100 & 88 \\
\hline & 10 & 160 & 292 & $190(20)$ & 55 & 379 & $97(45)$ & 100 & 89 \\
\hline & Overall & 160 & 292 & 191 (19) & 55 & 379 & $90(40)$ & 100 & 177 \\
\hline
\end{tabular}


reported by Brochert et al. [12] by over four months. Thus, juvenile rainbow trout and brown trout at the sizes used in this study can be safely tagged with 8 to $10 \mathrm{~mm}$ PIT tags with expectations of no mortality and near-total tag retention for nearly 10 to 12 months, respectively. The durations of other PIT tag studies involving juvenile salmonids and small tag sizes documenting tag retention rates and tagged fish survival similar to this study has been much shorter, ranging from 28 to 64 days [14] [17]. High tag retention of small PIT tags and low tagged fish mortality has also been documented in other small non-salmonid fish [18] [19] [20] [21].

In this study, the tag-to-body ratio never exceeded the $2 \%$ recommendation of Winter [22]. It should be noted however, that ratios of up to $6 \%$ have been successfully used in brown trout by Richard et al. [23]. In addition, the swimming of juvenile rainbow trout is unaffected by ratios approaching 12\% [24].

It is possible that the results of this study could have been influenced by the individuals tagging the fish and the conditions where the fish were reared. Different individuals with different levels of tagging experience, but no experience at all with small PIT tags, tagged the rainbow trout and brown trout in this study. The observed high retention rates and high fish survival indicate that the amount of tag experience was not an issue, in contrast to the observations of Dare [25], Meyer et al. [26], and Richard et al. [23]. Long-term rearing in the circular tank is obviously different than a natural situation with fluctuating water levels and variable environmental conditions that may impact tag retention [27]. However, the relatively high and constant water velocities used in the tank, the relatively crowded conditions potentially causing aggressive behaviors, and the disturbances associated with routine hatchery activities such as tank cleaning, suggest that the observed retention rates may be similar to what would occur in more natural environments.

\section{Conclusion}

In conclusion, this study indicates that 73 to $119 \mathrm{~mm}$ rainbow trout can be successfully implanted with 8,9 , and $10 \mathrm{~mm}$ PIT tags with minimal tag ejection and extremely high tagged fish survival for nearly one year. Brown trout ranging from 71 to $86 \mathrm{~mm}$ can also be successfully tagged for up to nearly ten months. These results will allow for the long-term monitoring of juvenile salmonids, providing another tool for use by fisheries managers and researchers.

\section{Acknowledgements}

We thank Jeremy Kientz, Eric Krebs, Misty Jones, and Charles Mordhorst for their assistance with this study.

\section{Conflicts of Interest}

The authors declare no conflicts of interest regarding the publication of this paper. 


\section{References}

[1] Hewitt, D.A, Janney, E.C., Hayes, B.S. and Shively, R.S. (2010) Improving Inferences from Fisheries Capture-Recapture Studies through Remote Detection of PIT tags. Fisheries, 35, 217-231. https://doi.org/10.1577/1548-8446-35.5.217

[2] Barbour, A.B., Adams, A.J., Behringer, D.C., Yess, T. and Wolfe, R.K. (2011) PIT Tag Antennae Arrays as Fishery Monitoring Tools in Tropical Environments. Proceedings of the 63 rd Gulf and Caribbean Fisheries Institute, San Juan, Puerto Rico, 1-5 November 2010, 118-124.

[3] Acolas, M.L., Roussel, J.M., Lebel, J.M. and Bagliniere, J.L. (2007) Laboratory Experiment on Survival, Growth and Tag Retention Following PIT Injection into the Body Cavity of Juvenile Brown Trout (Salmo trutta). Fisheries Research, 86, 280-284. https://doi.org/10.1016/j.fishres.2007.05.011

[4] Prentice, E.F., Flagg, T.A., McCutcheon, C.S., Brastow, D.F. and Cross, D.C. (1990) Equipment, Methods, and an Automated Data-Entry Station for Pit Tagging. American Fisheries Society Symposium, 7, 335-340.

[5] Ombredane, D., Bagliniere, J.L. and Marchand, F. (1998) The Effects of Passive Integrated Transponder Tags on Survival and Growth of Juvenile Brown Trout ( Salmo trutta L.) and Their Use for Studying Movement in a Small River. Hydrobiologia, 372, 99-106. https://doi.org/10.1023/A:1017022026937

[6] Cucherousset, J., Roussel, J.M., Keeler, R., Cunjak, R.A. and Stump, R. (2005) The Use of Two New Portable $12 \mathrm{~mm}$ PIT Tag Detectors to Track Small Fish in Shallow Streams. North American Journal of Fisheries Management, 25, 270-274. https://doi.org/10.1577/M04-053.1

[7] Teixeira, A. and Cortes, R.M.V. (2007) PIT Telemetry as a Method to Study the Habitat Requirements of Fish Populations: Application to Native and Stocked Trout Movements. Hydrobiologia, 582, 171-185. https://doi.org/10.1007/s10750-006-0551-Z

[8] Ward, D.L., Childs, M.R. and Persons, W.R. (2008) PIT Tag Retention and Tag Induced Mortality in Juvenile Bonytail and Gila Chub. Fisheries Management and Ecology, 15, 159-161. https://doi.org/10.1111/j.1365-2400.2008.00595.x

[9] Bryson, A.J., Woodley, C.M., Karis, R.K., Hall, K.D., Weiland, M.A., Deng, Z.D., Carlson, T.J. and Eppard, M.B. (2013) Comparison of 180-Degree and 90-Degree Needle Rotation to Reduce Wound Size in PIT-Injected Juvenile Chinook Salmon. Fisheries Research, 143, 201-204. https://doi.org/10.1016/j.fishres.2013.02.011

[10] Columbia Basin Fish and Wildlife Authority (1999) PIT Tag Marking Procedures Manual. PIT Tag Steering Committee, Portland, Oregon.

[11] Baras, E., Westerloppe, L., Melard, C., Philippart, J.C. and Benech, V. (1999) Evaluation of Implantation Procedures for PIT-Tagging Juvenile Nile Tilapia. North American Journal of Aquaculture, 61, 246-251. https://doi.org/10.1577/1548-8454(1999)061<0246:EOIPFP>2.0.CO;2

[12] Borchert, A., Davis, J.L. and Barnes, M.E. (2020) Retention of Passive Integrated Transponders (PIT) Tags in Juvenile Rainbow Trout and Brown Trout. Journal of FisheriesSciences.com, 14, 7-11.

[13] Skalski, J.R., Buchanan, R.A. and Griswold, J. (2009) Review of Marking Methods and Release-Recapture Designs for Estimating the Survival of Very Small Fish: Examples from the Assessment of Salmonid Fry Survival. Reviews in Fisheries Science, 17, 391-401. https://doi.org/10.1080/10641260902752199

[14] O’Donnell, M.J. and Letcher, B.H. (2017) Implanting 8-mm Passive Integrated Transponder Tags into Small Brook Trout: Effects on Growth and Survival in the 
Laboratory. North American Journal of Fisheries Management, 37, 605-611. https://doi.org/10.1080/02755947.2017.1307291

[15] Hikasa, Y., Takase, K., Ogasawara, T. and Ogasawara, S. (1986) Anesthesia and Recovery with Tricaine Methane Sulfonate, Eeugenol and Thiopental Sodium in the Carp, Cyprinus carpio. Japanese Journal of Veterinary Science, 48, 341-351. https://doi.org/10.1292/jvms1939.48.341

[16] Warton, D.I. and Hui, F.K.C. (2011) The Arcsine Is Asinine: The Analysis of Proportions in Ecology. Ecology, 92, 3-10. https://doi.org/10.1890/10-0340.1

[17] Tiffan, K.F., Perry, R.W., Connor, W.P., Mullins, F.L., Rabe, C.D. and Nelson, D.D. (2015) Survival, Growth, and Tag Retention in Age-0 Chinook Salmon Implanted with 8-, 9-, and 12-mm PIT Tags. North American Journal of Fisheries Management, 35, 845-852. https://doi.org/10.1080/02755947.2015.1052163

[18] Ashton, N.K., Ireland, S.C. and Cain, K.D. (2013) Artificial Marker Selection and Subsequent Tagging Evaluations with Juvenile Burbot. Transactions of the American Fisheries Society, 142, 1688-1698. https://doi.org/10.1080/00028487.2013.788558

[19] Ward, L., Persons, W.R., Young, K.L., Stone, D.M., Vanhaverbeke, D.R. and Knight, W.K. (2015) A Laboratory Evaluation of Tagging-Related Mortality and Tag Loss in Juvenile Humpback Chub. North American Journal of Fisheries Management, 35, 135-140. https://doi.org/10.1080/02755947.2014.986345

[20] Pennock, C.A., Frenette, B.D., Waters, M.J. and Gido, K.B. (2016) Survival of and Tag Retention in Southern Redbelly Dace Injected with Two Sizes of PIT Tags. North American Journal of Fisheries Management, 36, 1386-1394. https://doi.org/10.1080/02755947.2016.1227403

[21] Cary, J.B., Holbrook, J.L., Reed, J.L., Austin, T.B., Steffensen, M.S., Kim, S., Pregler, K.C. and Kanno, Y. (2017) Survival of Upper Piedmont Stream Fishes Implanted with 8-mm Passive Integrated Transponder Tags. Transactions of the American Fisheries Society, 146, 1223-1232. https://doi.org/10.1080/00028487.2017.1370015

[22] Winter, J.D. (1983) Underwater Biotelemetry. In: Nielsen, L.A. and Johnson, D.L., Eds., Fisheries Techniques, American Fisheries Society, Bethesda, MD, 371-395.

[23] Richard, A., O’Rourke, J., Caudron, A. and Cattanéo, F. (2013) Effects of Passive Integrated Transponder Tagging Methods on Survival, Tag Retention and Growth of Age-0 Brown Trout. Fisheries Research, 145, 37-42. https://doi.org/10.1016/j.fishres.2013.03.001

[24] Brown, R.S., Cooke, S.J., Anderson, W.G. and McKinley, R.S. (1999) Evidence to Challenge the "2\% Rule" for Biotelemetry. North American Journal of Fisheries Management, 19, 867-871.

https://doi.org/10.1577/1548-8675(1999)019<0867:ETCTRF>2.0.CO;2

[25] Dare, M.R. (2003) Mortality and Long-Term Retention of Passive Integrated Transponder Tags by Spring Chinook Salmon. North American Journal of Fisheries Management, 23, 1015-1019. https://doi.org/10.1577/M02-106

[26] Meyer, K.A., High, B., Gastelecutto, N., Mamer, E.R.J. and Elle, F.S. (2011) Retention of Passive Integrated Transponder Tags in Stream Swelling Rainbow Trout. North American Journal of Fisheries Management, 31, 236-239. https://doi.org/10.1080/02755947.2011.572799

[27] Dieterman, D.J. and Hoxmeier, J.H. (2009) Instream Evaluation of Passive Integrated Transponder Retention in Brook Trout and Brown Trout: Effects of Season, Anatomical Placement, and Fish Length. North American Journal of Fisheries Management, 29, 109-115. https://doi.org/10.1577/M07-223.1 